\title{
High formation of secondary organic aerosol from the photo-oxidation of toluene
}

\author{
L. Hildebrandt ${ }^{1}$, N. M. Donahue ${ }^{1}$, and S. N. Pandis ${ }^{1,2}$ \\ ${ }^{1}$ Center for Atmospheric Particle Studies, Carnegie Mellon University, 5000 Forbes Ave., Pittsburgh, PA 15213, USA \\ ${ }^{2}$ Institute of Chemical Engineering and High Temperature Chemical Processes (ICE-HT), Foundation of Research and \\ Technology (FORTH), Patra, Greece
}

Received: 31 October 2008 - Published in Atmos. Chem. Phys. Discuss.: 9 January 2009

Revised: 6 April 2009 - Accepted: 29 April 2009 - Published: 7 May 2009

\begin{abstract}
Toluene and other aromatics have long been viewed as the dominant anthropogenic secondary organic aerosol (SOA) precursors, but the SOA mass yields from toluene reported in previous studies vary widely. Experiments conducted in the Carnegie Mellon University environmental chamber to study SOA formation from the photooxidation of toluene show significantly larger SOA production than parameterizations employed in current air-quality models. Aerosol mass yields depend on experimental conditions: yields are higher under higher UV intensity, under low- $\mathrm{NO}_{\mathrm{x}}$ conditions and at lower temperatures. The extent of oxidation of the aerosol also varies with experimental conditions, consistent with ongoing, progressive photochemical aging of the toluene SOA. Measurements using a thermodenuder system suggest that the aerosol formed under high- and low- $\mathrm{NO}_{\mathrm{x}}$ conditions is semi-volatile. These results suggest that SOA formation from toluene depends strongly on ambient conditions. An approximate parameterization is proposed for use in air-quality models until a more thorough treatment accounting for the dynamic nature of this system becomes available.
\end{abstract}

\section{Introduction}

Fine particles affect climate (IPCC, 2007) and human health (Dockery et al., 1993; Davidson et al., 2005). The organic component of aerosol particles comprises about one half of the fine-particle mass on average (Kanakidou et al., 2005; Zhang et al., 2007). Recent work has shown that most of the organic-aerosol mass is oxygenated organic aerosol (OOA)

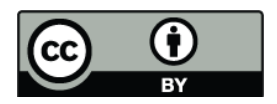

Correspondence to: S. Pandis (spyros@andrew.cmu.edu)
(Volkamer et al., 2006). Most of the OOA is expected to be secondary organic aerosol (SOA), which is produced when volatile organic compounds (VOCs) or semi-volatile organic compounds (SVOCs) are oxidized in the gas phase, forming less volatile products that can then partition to the particle phase. Thus, SOA is expected to comprise a significant fraction of the atmospheric fine-particle mass. Air-quality models currently under-predict the concentrations of organic aerosol in the atmosphere, especially in the summer and in urban areas (Volkamer et al., 2006; Goldstein and Galbally, 2007; Karydis et al., 2007), suggesting that we do not understand anthropogenic SOA formation well.

Toluene (methylbenzene) and other light aromatics are thought to be the dominant anthropogenic SOA precursors (Pandis et al., 1992; Koo et al., 2003; Vutukuru et al., 2006). The emissions of toluene in the US are approximately $1 \mathrm{TgC} \mathrm{yr}^{-1}$, and seasonal variations are small (LADCO, 1999). In addition to being an important SOA precursor itself, toluene serves as a model system to study the formation of SOA from other aromatic VOCs.

The ability of a precursor to form SOA is usually described by a fractional aerosol mass yield - the mass of aerosol formed divided by the mass of VOC reacted. The aerosol mass yields from the photo-oxidation of toluene reported in the literature vary widely. In general, earlier studies (Stern, 1988; Izumi and Fukuyama, 1990; Forstner, 1996; Kleindienst et al., 1999, 2004; Hurley et al., 2001) reported smaller yields than more recent studies (Takekawa et al., 2003; $\mathrm{Ng}$ et al., 2007), but a direct comparison is often difficult because studies were conducted under different conditions and with different aerosol mass loadings. Forstner (1996) measured a yield of $0.2 \%$ at $1 \mu \mathrm{g} \mathrm{m}^{-3}$ aerosol mass loading, Kleindienst et al. (1999) $1.6 \%$ at $8 \mu \mathrm{g} \mathrm{m}^{-3}$, Stern (1988) $2.5 \%$ at $30 \mu \mathrm{g} \mathrm{m}^{-3}$ and Hurley et al. (2001) $2.5 \%$ at $50 \mu \mathrm{g} \mathrm{m}^{-3}$. In more recent studies, $\mathrm{Ng}$

Published by Copernicus Publications on behalf of the European Geosciences Union. 
et al. (2007) reported a yield of $11 \%$ at $23 \mu \mathrm{g} \mathrm{m}^{-3}$ under high- $\mathrm{NO}_{\mathrm{x}}$ conditions ([Toluene $]_{0} /[\mathrm{NO}]_{0} \sim 3.5(\mathrm{ppbC} / \mathrm{ppb})$, $\left.[\text { Toluene }]_{0} /[\mathrm{NO}]_{0} \sim 1.5(\mathrm{ppbC} / \mathrm{ppb})\right)$ and an approximately constant yield of $30 \%$ under low- $\mathrm{NO}_{\mathrm{x}}$ conditions. $\mathrm{Ng}$ et al. (2007) suggested that the constant yield with aerosol loading under low- $\mathrm{NO}_{\mathrm{x}}$ conditions implies that the SOA formed can be represented as a single product with very low volatility. Takekawa et al. (2003) found a yield of $20 \%$ at $283 \mathrm{~K}$ and $97 \mu \mathrm{g} \mathrm{m}^{-3}$ ([Toluene $]_{0} /[\mathrm{NO}]_{0} \sim 240(\mathrm{ppbC} / \mathrm{ppb}$ ), $\left.[\text { Toluene }]_{0} /[\mathrm{NO}]_{0} \sim 80(\mathrm{ppbC} / \mathrm{ppb})\right)$ and a yield about a factor of 2 smaller at $303 \mathrm{~K}$ and $57 \mu \mathrm{g} \mathrm{m}^{-3}$ ([Toluene $]_{0} /[\mathrm{NO}]_{0} \sim 208(\mathrm{ppbC} / \mathrm{ppb}), \quad[\text { Toluene }]_{0} /[\mathrm{NO}]_{0} \sim$ 69 (ppbC/ppb)).

Differences in experimental conditions may cause these differences in measured aerosol yields. For example, Hurley et al. (2001) did not use seed aerosol in their experiments, which can affect the losses of semi-volatile compounds to the chamber walls (Kroll et al., 2007; Pathak et al., 2007). Forstner (1996), Stern (1988), Kleindienst et al. (1999), Takekawa et al. (2003) and Hurley et al. (2001) conducted "classical" photo-oxidation experiments, starting with a toluene/ $\mathrm{NO}_{\mathrm{x}}$ mixture plus propylene or $\mathrm{CH}_{3} \mathrm{ONO}$, expecting that propylene would enhance photochemistry by increasing $\mathrm{OH}$ concentrations. Song et al. (2007) have shown that propylene does not enhance the concentration of $\mathrm{OH}$ in chamber experiments - it actually reduces them. More recent studies of toluene photo-oxidation have used direct $\mathrm{OH}$ sources: $\mathrm{HOOH}$ in low- $\mathrm{NO}_{\mathrm{x}}$ experiments and $\mathrm{HONO}$ in high- $\mathrm{NO}_{\mathrm{x}}$ experiments (e.g. $\mathrm{Ng}$ et al., 2007). Takekawa et al. (2003) did not add $\mathrm{OH}$ enhancers in their high- $\mathrm{NO}_{\mathrm{x}}$ experiments. Several studies have suggested that the SOA from toluene is formed from further oxidation of initial toluene photo-oxidation products (Hurley et al., 2001; Takekawa et al., 2003), implying that several oxidation steps are required before aerosol can be formed. The presence of multiple generations of oxidation products could well explain the variability among various experiments. For example, using a more direct $\mathrm{OH}$ source such as $\mathrm{HOOH}$ or $\mathrm{HONO}$ may result in higher $\mathrm{OH}$ concentrations and therefore faster oxidation, leading to more functionalized products with lower volatility, resulting in higher aerosol mass yields.

Temperature is also an important factor in determining aerosol yields (Takekawa et al., 2003). Stern (1988) and Forstner (1996) conducted their experiments in an outdoor chamber without temperature control, resulting in average temperatures as high as $49^{\circ} \mathrm{C}$. These high temperatures are expected to result in lower aerosol mass yields. In addition, none of the studies mentioned above accounted for the loss of condensable vapors to the walls of the chambers. Over the course of each chamber experiment, organic mass builds up on the walls of the chamber by the deposition of particles. Organic vapors can then condense on this organic wall mass. This effect is expected to increase over the course of an experiment, so it might be particularly significant for long experiments with slowly reacting VOCs like toluene. The amount of liquid water in the aerosol seed also appears to affect the aerosol mass yield, but the magnitude of this effect remains uncertain (Edney et al., 2000; Hennigan et al., 2008; Volkamer et al., 2009). The organic aerosol yields do not seem to be affected by acidities typically found in the atmosphere (Ng et al., 2007).

This work addresses a number of questions raised by the previous studies. Toluene photo-oxidation experiments are performed under different conditions in order to:

1. Investigate the discrepancy between the low yields measured in earlier studies (less than 3\% for ambient conditions) and the higher values (10-30\% for similar conditions) reported more recently.

2. Propose and apply a method to correct aerosol mass yields for the loss of organic vapors to the walls of the chamber.

3. Study the dependence of aerosol mass yields on UV intensity, temperature and the level of $\mathrm{NO}_{\mathrm{x}}$.

4. Directly measure the volatility of the organic aerosol using a thermodenuder system.

5. Characterize organic aerosol formed under the different experimental conditions for extent of oxidation.

6. Suggest new parameters to be used in air-quality models for aerosol yields from toluene and other small aromatic compounds.

\section{Materials and methods}

\subsection{Experimental setup}

Batch experiments were conducted in the environmental chamber of Carnegie Mellon's Center for Atmospheric Particle Studies (CAPS). The chamber is a $12 \mathrm{~m}^{3}$ Teflon bag (Welch Fluorocarbon) suspended inside a temperaturecontrolled room. Before each experiment, the bag was cleaned with dry, clean air created by passing compressed air through high-efficiency particulate air (HEPA) filters and activated-carbon filters to remove particles and organic vapors, and through silica gel to remove moisture. For each experiment, hydrogen peroxide $\left(\mathrm{H}_{2} \mathrm{O}_{2}\right)$ was then introduced into the chamber by bubbling clean, heated air through a 50/50 solution of $\mathrm{H}_{2} \mathrm{O}_{2}$ in water (Sigma Aldrich). Introducing $\mathrm{H}_{2} \mathrm{O}_{2}$ into the chamber also introduced water vapor, resulting in modest variability in relative humidity between experiments (Table 1). Ammonium sulfate $\left(\left(\mathrm{NH}_{4}\right)_{2} \mathrm{SO}_{4}\right.$, Sigma Aldrich, 99.99\%) seed particles were created using a constant-output atomizer (TSI, model 3075) and were passed through a diffusion dryer and a neutralizer into the chamber. Nitric oxide (NO) was added to the chamber for high- $\mathrm{NO}_{\mathrm{x}}$ $\left(=\mathrm{NO}+\mathrm{NO}_{2}\right)$ experiments using a high-pressure gas cylinder 
Table 1. Experimental conditions and summary of results.

\begin{tabular}{|c|c|c|c|c|c|c|c|c|c|c|c|}
\hline Exp. & $\begin{array}{c}\text { [Toluene }]_{0}^{\mathrm{a}} \\
(\mathrm{ppb})\end{array}$ & $\begin{array}{c}{\left[\mathrm{NO}_{\mathrm{x}}\right]_{0}^{\mathrm{b}}} \\
(\mathrm{ppb})\end{array}$ & $\begin{array}{l}T_{\mathrm{avg}}^{\mathrm{c}} \\
\left({ }^{\circ} \mathrm{C}\right)\end{array}$ & $\begin{array}{c}{\left[\mathrm{H}_{2} \mathrm{O}_{2}\right]_{0}^{\mathrm{d}}} \\
(\mathrm{ppm})\end{array}$ & $\begin{array}{c}{[\text { Seed }]_{0}^{\mathrm{e}}} \\
\left(\mu \mathrm{g} \mathrm{m}^{-3}\right)\end{array}$ & $\begin{array}{c}{[\mathrm{OH}]^{\mathrm{f}}} \\
* 10^{6} \\
\mathrm{~cm}^{-3}\end{array}$ & $\begin{array}{l}\mathrm{RH} \\
(\%)\end{array}$ & $\begin{array}{l}\text { Lights } \\
(\%)\end{array}$ & $\begin{array}{c}\text { Aerosol } \\
\text { Mass } \\
\text { Yield at } \\
C_{\mathrm{OA}}= \\
10 \mu \mathrm{g} \mathrm{m}^{-3} \\
(\%)\end{array}$ & $\begin{array}{c}\text { Aerosol } \\
\text { Mass } \\
\text { Yield at } \\
C_{\mathrm{OA}}= \\
20 \mu \mathrm{g} \mathrm{m}^{-3} \\
(\%)\end{array}$ & $\begin{array}{c}m / z 44^{\mathrm{h}} \\
(\%)\end{array}$ \\
\hline 1 & 940 & 1300 & 20 & 49 & 61 & 3.1 & 13 & 30 & 8 & 12 & 6 \\
\hline 2 & 380 & 720 & 20 & 72 & 64 & 3.5 & 13 & 100 & 16 & 21 & 9 \\
\hline 3 & 950 & 570 & 20 & 91 & 113 & 2.6 & 21 & 100 & 11 & 17 & 9 \\
\hline 4 & 190 & 320 & 18 & 87 & 50 & 1.9 & 15 & 100 & 28 & 37 & 10 \\
\hline 5 & 180 & 270 & 12 & 57 & 42 & 1.1 & 12 & 100 & 32 & 44 & 10 \\
\hline 6 & 200 & 430 & 31 & 85 & 36 & 2.4 & 5 & 100 & 19 & 26 & 11 \\
\hline 7 & 380 & $<5$ & 20 & 88 & 59 & 1.6 & 13 & 100 & 26 & 41 & 8 \\
\hline 8 & 270 & $<5$ & 11 & 40 & 57 & 1.0 & 16 & 100 & 29 & 40 & 8 \\
\hline 9 & 180 & $<5$ & 11 & 46 & 45 & 0.6 & 14 & 100 & 49 & 66 & 8 \\
\hline 10 & 200 & $<5$ & 32 & 42 & 60 & 1.2 & 4 & 100 & 23 & 31 & 14 \\
\hline 11 & 570 & $<5$ & 21 & 87 & 61 & 1.4 & 9 & 100 & 18 & 26 & 8 \\
\hline 12 & 570 & $<5$ & 21 & 45 & 47 & 1.6 & 9 & 100 & 20 & 26 & 8 \\
\hline $13^{\mathrm{i}}$ & 180 & 330 & 11.6 & 99 & 62 & 0.8 & 22 & 100 & & & \\
\hline
\end{tabular}

a Subscript 0 denotes initial condition (immediately before UV lights are turned on).

${ }^{b} \mathrm{NO}_{\mathrm{x}}$ was initially present as $\mathrm{NO}$, but was converted to $\mathrm{NO}_{2}$ within minutes after the UV lights were turned on.

${ }^{\mathrm{c}}$ Temperature averaged for the duration of the experiment. Temperature fluctuations during the experiment are less than $2^{\circ} \mathrm{C}$.

${ }^{d} \mathrm{H}_{2} \mathrm{O}_{2}$ concentrations are not measured directly but are approximated from $\mathrm{H}_{2} \mathrm{O}_{2}$ interference in a UV photometric ozone monitor.

e Initial seed concentrations from SMPS measurements, using density of $1.77 \mathrm{~g} \mathrm{~cm}^{-3}\left(\right.$ dry $\left.\left(\mathrm{NH}_{4}\right)_{2} \mathrm{SO}_{4}\right)$.

${ }^{\mathrm{f}} \mathrm{OH}$ concentrations were not measured directly but are approximated from the first-order decay of toluene observed in the PTR-MS

$\mathrm{g}$ Mass concentration and aerosol mass yield of SOA calculated from the AMS for case 2.

$\mathrm{h}$ Calculated from relative organic spectra from the AMS. Reported values are averaged for hours 1-3 of each photo-oxidation experiment. The variation of $m / z, 44$ during this time period was minimal in all experiments.

${ }^{\mathrm{i}}$ Experiment was not used for yield calculations due to poor AMS calibration that day. The calibration does not affect $f^{\text {sus }}$, used for volatility calculations.

of $0.01 \% \mathrm{NO}$ in $\mathrm{N}_{2}$ (Valley National Gas). $\mathrm{NO}_{2}$ was produced via the $\mathrm{NO}+\mathrm{O}_{3}$ reaction and was not directly added to the chamber. Toluene (Sigma-Aldrich, 99\%) was introduced to the chamber via a septum injector in which clean air was passed over the injected liquid toluene to vaporize and transfer it to the chamber. The walls of the temperature-controlled room are lined with UV lights (General Electric model 10526 black). After the particles and gases were injected into the chamber and allowed to mix, the UV lights were turned on to initiate photo-oxidation reactions and SOA formation.

Particle number and volume inside of the chamber were measured using a scanning mobility particle sizer (SMPS, TSI classifier model 3080, CPC model 3071 or 3010). In order to convert the SMPS volume measurements to mass concentrations, an organic mass density of $1.4 \mathrm{~g} \mathrm{~cm}^{-3}$ was used based on literature data (Ng et al., 2007). Particle mass was also measured directly by a Quadrupole Aerosol Mass Spectrometer (Q-AMS, Aerodyne Research, Inc.). The Q-AMS alternated between operating in mass spectrum (MS) scanning mode and in particle time-of-flight (PToF) mode every fifteen seconds (Jayne et al., 2000; Jimenez et al., 2003). The sample averaging time was set at five minutes, and the va- porizer temperature was $600^{\circ} \mathrm{C}$ to ensure complete vaporization of the ammonium sulfate seed. The AMS provides three separate quantities important to the SOA measurements: the aerosol size distribution based on the vacuum aerodynamic diameter, the total organic mass, and the ratio of organic to sulfate mass. The organic to sulfate ratio is the most precise of these measurements and thus forms the basis for our estimates of net SOA formation. Measurements of organic mass using the AMS are not dependent on an assumed organic density. The collected data were analyzed using the standard AMS fragmentation table (Allan et al., 2004), with a few modifications as follows: The particle mass appearing at mass-to-charge ratio $(\mathrm{m} / \mathrm{z}) 39$, entirely attributed to potassium in the standard fragmentation table, was here attributed to organic material. The particles formed in these experiments are not expected to contain potassium, and the time trend of $\mathrm{m} / \mathrm{z} 39$ clearly followed that of the organic signal. Further, all nitrate observed by the AMS in these chamber experiments is assumed to be due to organic nitrate; therefore, the nitrate signal from the AMS was added to the organic signal for aerosol mass yield calculations. 
Concentrations of toluene were monitored using a protontransfer reaction mass spectrometer (PTR-MS, Ionicon Analytik GmbH). PTR-MS measurements of toluene were corrected for ion-source intensity and humidity as suggested by de Gouw et al. (2003) using their measured, compoundspecific parameter for toluene. Toluene measurements were calibrated in two different ways: 1) Offline, by comparison to toluene concentrations measured via gas chromatography with a flame ionization detector (GC-FID, Perkin-Elmer AutoSystem XL; J\&W Scientific DB-624 capillary column, $30 \mathrm{~m} \times 0.530 \mathrm{~mm}$ ) after preconcentration (Entech 7100A); and, 2) Online, by comparison to the toluene volume injected into the chamber. Online calibrations were preformed for each experiment; offline calibrations were performed periodically, and they agreed well with online calibrations. A sensitivity factor (ppb toluene/normalized counts measured by the PTR-MS) was thus calculated and applied to all experiments. The first-order decay of toluene was used to estimate hydroxyl radical concentrations.

Ozone and $\mathrm{NO}_{\mathrm{x}}$ concentrations were measured by gas-phase analyzers (Monitor Labs model 8410, API model 200A). Temperature and relative humidity were measured using thermistors and a commercial humidity sensor (Vaisala). Initial hydrogen peroxide concentrations were estimated from interference in a UV photometric ozone analyzer (Dasibi model 1008 PC). Table 1 summarizes the experimental conditions of the experiments presented here.

The volatility of SOA produced from the photo-oxidation of toluene was analyzed using the thermodenuder system described by An et al. (2007). The SOA generated in the chamber passes alternatively through the thermodenuder, heated to a predefined temperature, or a bypass line. The aerosol flow direction is controlled by two 3 -way valves. Activated charcoal is used in the cooling stage to adsorb the organic vapors and thereby avoid recondensation. Particles are sent through the same sampling line to an SMPS for measurement of the online particle size distribution and to the Q-AMS for real-time measurement of the aerosol chemical composition. The volatility is then determined by comparing the residual aerosol after the thermodenuder to the aerosol that was passed through the bypass.

\subsection{Quantifying SOA production}

The aerosol mass yield, $Y$, is defined as the ratio of the concentration of aerosol formed, divided by the mass of VOC reacted:

$Y=\frac{C_{\mathrm{OA}}}{\Delta C_{\mathrm{tol}}}$

where $C_{\mathrm{OA}}$ is the total mass concentration of organic aerosol in the system and $\Delta C_{\text {tol }}$ is the change in the mass concentration of toluene. The objective of an experiment is thus to measure the above two quantities and therefore the aerosol mass yield.
The SOA is assumed to be in equilibrium, and the partitioning of organic compounds between the gas and particle phase can be characterized by an effective saturation mass concentration $C_{i}^{*}$. The fraction of a given compound $i$ in the condensed (particle) phase is given by Donahue et al. (2006):

$\xi_{i}=\left(1+\frac{C_{i}^{*}}{C_{\mathrm{OA}}}\right)^{-1}$ with $C_{\mathrm{OA}}=\sum_{i} C_{i} \xi_{i}$

where $C_{i}$ is the concentration of compound $i$ in the particle phase.

\subsubsection{Calculating the total SOA concentration in the chamber}

Observations of the suspended particle mass concentration must be corrected for losses to the chamber walls. Wall losses come in two forms: direct deposition of particles to the walls, and mass transfer of condensable vapors to the walls - most probably onto previously deposited particles. Deposition of particles has been addressed extensively before (Crump and Seinfeld, 1981; McMurry and Rader, 1985; Pierce et al., 2008). Mass transfer of organic vapors to the walls has not received as much attention, and it is a more vexing problem because it is not directly constrained by measurements.

The presence of inorganic seeds allows us to formulate the problem in terms of the mass balance of inorganic and organic material. The mass of the inorganic material changes only due to deposition of particles to the walls, consequently,

$\frac{d}{d t}\left[C_{\text {seed }}^{\text {sus }}\right]=-k_{w}(t) C_{\text {seed }}^{\text {sus }}$

where $C_{\text {seed }}^{\text {sus }}$ is the concentration of seed aerosol in suspension and $k_{w}(t)$ is the time-dependent rate constant for mass loss due to particle deposition onto the walls (henceforth referred to as wall deposition constant). Similarly, the change in the seed-particle mass on the walls is:

$$
\frac{d}{d t}\left[C_{\text {seed }}^{\text {wall }}\right]=k_{w}(t) C_{\text {seed }}^{\text {sus }}
$$

The change in the suspended organic particle mass in the chamber $C_{\mathrm{OA}}^{\text {sus }}$ is:

$$
\frac{d}{d t}\left[C_{\mathrm{OA}}^{\mathrm{sus}}\right]=-k_{w}(t) C_{\mathrm{OA}}^{\mathrm{sus}}+P^{\mathrm{sus}}
$$

where $k_{w}(t) C_{\mathrm{OA}}^{\mathrm{sus}}$ is the loss rate of organic particle mass to the chamber walls due to deposition and $P^{\text {sus }}$ is the net rate of mass transfer of organic vapors to the suspended particles (condensation - evaporation). In the above equation we implicitly assume that the wall deposition constant $k_{w}(t)$ of the organic material is the same as that of the inorganic material, i.e. that organics and inorganics are internally mixed. This assumption will be addressed in Sect. 3 . 
The change in organic particle mass on the walls $C_{\mathrm{OA}}^{\text {wall }}$ is given by:

$\frac{d}{d t}\left[C_{\mathrm{OA}}^{\mathrm{wall}}\right]=k_{w}(t) C_{\mathrm{OA}}^{\mathrm{sus}}+P^{\mathrm{wall}}$

where $P^{\text {wall }}$ is the net rate of mass transfer of organic vapors to the chamber walls. The methods to determine $P^{\text {sus }}$ and $P^{\text {wall }}$ from SMPS and AMS data are described in more detail below. The goal is to determine the total organic aerosol concentration, $C_{\mathrm{OA}}=C_{\mathrm{OA}}^{\mathrm{sus}}+C_{\mathrm{OA}}^{\text {wall }}$, so that we can use it in Eq. (1) to calculate the corresponding aerosol mass yield. $C_{\mathrm{OA}}^{\text {wall }}$ and $C_{\text {seed }}^{\text {wall }}$ are ratios of the mass on the wall to the volume of the chamber and therefore have units of $\mu \mathrm{g} \mathrm{m}^{-3}$.

The wall deposition constant depends on the particle size and charge distribution and the level of turbulence inside the chamber. It is estimated semi-empirically here by fitting the observed wall loss before and after each experiment, using measurements when the UV lights are turned off and wall loss is the only process changing the total suspended particle mass in the chamber. To account for wall loss throughout the experiment, $k_{w}$ is interpolated linearly with time for the duration of the experiment.

\subsubsection{Condensation of organic vapors to chamber walls}

To determine $P^{\text {wall }}$, we assume that condensable vapors are not lost to the clean Teflon walls, but instead condense onto particles that have been deposited to the walls. This is a complex process, so here we will limit our analysis to constraining the problem with two limiting cases. Case 1 assumes that the condensable products only partition to the suspended particles, so there is no wall condensation and $P^{\text {wall }}=0$. Previous wall-loss treatments that only account for particle deposition onto the chamber walls are consistent with this assumption. Case 2 assumes that condensation to the particles on the walls is not slowed by any additional mass-transfer resistances, so the particles on the walls are in equilibrium with the organic vapors and behave exactly as if they were suspended. There is no obvious reason why particles deposited to the chamber walls should completely lose contact with the vapors in the chamber, a conclusion supported by the precursor spiking experiments of Weitkamp et al. (2007). However, we cannot rule out a mass-transfer limitation to the walls, and a conservative approach is to treat these two limiting cases, while noting that the true behavior of the system may be somewhere in between. Mass transfer of organic vapors to the walls $\left(P^{\text {wall }}\right)$ in case 2 scales with the particle mass fraction on the walls. Therefore, the limiting cases diverge and uncertainty in the observed SOA production increases during an experiment.

\subsubsection{Estimating SOA production based on SMPS data}

Using $k_{w}(t)$ estimated as explained above, the initial inorganic seed aerosol concentration measured by the SMPS and the inorganic density $\rho_{\text {seed }}$, the predicted seed aerosol mass in suspension throughout the experiment is

$C_{\text {seed }}^{\text {sus }}(t)=\rho_{\text {seed }} V_{\text {sus }}^{\text {seed }}(0) \exp \left[-\int_{0}^{t} k_{w}(t) d t\right]$

The suspended organic-aerosol mass concentration measured by the SMPS is proportional to the difference between the measured volume, $V_{\text {SMPS }}$, and the inorganic aerosol volume:

$C_{\mathrm{OA}}^{\mathrm{sus}}(t)=\rho_{\mathrm{OA}}\left(V_{\mathrm{SMPS}}(t)-\frac{C_{\mathrm{seed}}^{\mathrm{sus}}(t)}{\rho_{\text {seed }}}\right)$

An inorganic density of $\rho_{\text {seed }}=1.77 \mathrm{~g} / \mathrm{cm}^{-3}$ (dry ammonium sulfate) and organic density of $\rho_{\mathrm{OA}}=1.4 \mathrm{~g} / \mathrm{cm}^{-3}$ based on literature data ( $\mathrm{Ng}$ et al., 2007) is used to convert aerosol volume to suspended aerosol mass concentrations.

In the two limiting cases, the calculations are straightforward. Neglecting condensation onto the walls (case 1), $P^{\text {wall }}(t)=0$ and

$C_{\mathrm{OA}}(t)=C_{\mathrm{OA}}^{\mathrm{sus}}(t)+\int_{0}^{t} k_{w}(t) C_{\mathrm{OA}}^{\mathrm{sus}}(t) d t$

where the second term is just the integral of Eq. (6). This case provides a lower limit for SOA formation, and it is by far the most widely applied in the literature. For case 2, the organic to sulfate ratio remains the same for the suspended and walldeposited particles because there are no mass-transfer limitations between the particles in suspension and those on the walls. Because the mass of ammonium sulfate is conserved in the combined system (suspended + walls): $\frac{d}{d t}\left[C_{\text {seed }}\right]=0$, the amount of organic aerosol formed can be calculated by multiplying the ratio of suspended organic aerosol to inorganic seed aerosol by the total initial mass of seed aerosol. Thus,

$C_{\mathrm{OA}}(t)=\frac{C_{\mathrm{OA}}^{\mathrm{sus}}(t)}{C_{\text {seed }}^{\text {sus }}(t)} C_{\text {seed }}^{\text {sus }}(t=0)$

where $t=0$ corresponds to the time when the lights were turned on, starting photochemistry and the formation of organic aerosol.

\subsubsection{Estimating SOA production from AMS data}

In the AMS, $C_{\mathrm{OA}}^{\mathrm{sus}}(t)$ and $C_{\text {seed }}^{\text {sus }}(t)$ are measured directly and do not need to be calculated. The ratio of suspended organic mass and suspended seed mass can thus be determined without the need to estimate the wall deposition constant. Assuming that the particles are internally mixed, this ratio is independent of the collection efficiency $(\mathrm{CE})$ of particles in the AMS, which is uncertain and can change over the course of an experiment. In the experiments conducted here, for example, the $\mathrm{CE}$ of the particles increases when organics start 


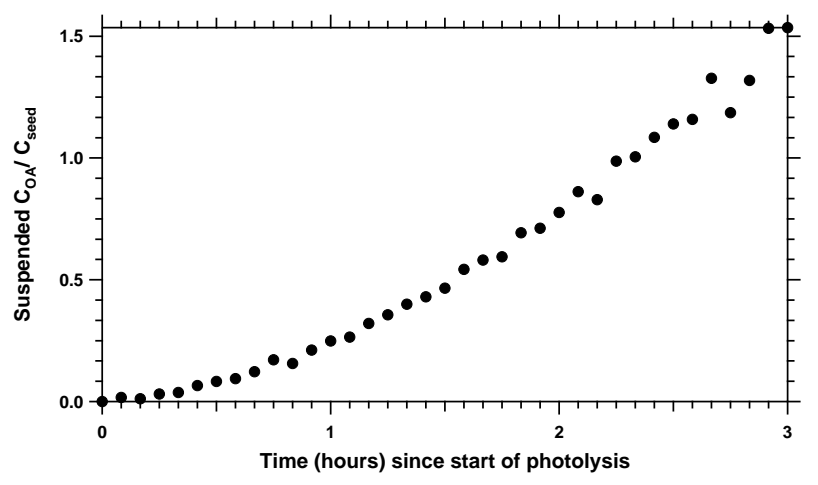

Fig. 1. Evidence for sustained SOA production: time series measurements of the ratio of organic to seed mass as measured by the AMS for experiment 12 .

forming on the seed particles, presumably because the organic material reduces particle bounce on the vaporizer of the instrument. This variation of $\mathrm{CE}$ in the AMS and the associated uncertainty in the absolute mass measurement is why we do not use the AMS to calculate $C_{\mathrm{OA}}$ for case 1 . For case 2, where the wall-deposited particles behave as if they were suspended, the amount of aerosol formed can be calculated by Eq. (10). The SMPS measurement of the initial ammonium sulfate concentration is used for this calculation since it is not prone to uncertainties regarding the collection efficiency and is thus deemed to be more accurate.

Figure 1 shows $C_{\mathrm{OA}}^{\text {sus }} / C_{\text {seed }}^{\text {sus }}$ measured using the AMS during a typical low- $\mathrm{NO}_{\mathrm{x}}$ experiment (Experiment 12). The initial ammonium sulfate concentration was $47 \mu \mathrm{g} \mathrm{m}^{-3}$. After $80 \mathrm{~min}$ of photo-oxidation, $126 \mu \mathrm{g} \mathrm{m}^{-3}$ of toluene had been oxidized and $C_{\mathrm{OA}}^{\text {sus }} / C_{\text {seed }}^{\text {sus }} \sim 1$, so $47 \mu \mathrm{g} \mathrm{m}^{-3}$ of SOA had been formed, and the SOA mass yield was $37 \%$ for this case.

\subsection{Composition of organic aerosol - extent of oxidation}

Relative spectra, the fractional contributions of the organic fragment at each $\mathrm{m} / \mathrm{z}$ to the total organic mass, are calculated from the Q-AMS data. The mass fragment at $m / z 44$ mostly corresponds to the $\mathrm{CO}_{2}^{+}$ion (Aiken et al., 2008) and can therefore be used as a semi-empirical measure of the extent of oxidation in the system. Aiken et al. (2008) have shown that the fraction of organic mass at $\mathrm{m} / \mathrm{z}, 44$ can be used to approximate the oxygen to carbon $(\mathrm{O} / \mathrm{C})$ ratio in the organic aerosol. They found significant correlation between $\mathrm{O} / \mathrm{C}$ and $\mathrm{m} / \mathrm{z} 44$ described by the following least-squares fit:

$(\mathrm{O} / \mathrm{C})=3.82 \frac{\left[\mathrm{m} / \mathrm{z}^{44}\right]\left(\mu \mathrm{g} \mathrm{m}^{-3}\right)}{C_{\mathrm{OA}}\left(\mu \mathrm{g} \mathrm{m}^{-3}\right)}+0.0794$

This correlation was mostly derived from ambient measurements in Mexico City, so the applicability to the data presented here is uncertain. However, it can still provide an estimate of the $\mathrm{O} / \mathrm{C}$ ratio of the organic aerosol formed in these experiments, and the fraction of the organic signal at $\mathrm{m} / \mathrm{z} 44$ is still expected to be correlated with the extent of oxidation of the SOA.

\subsection{Volatility of SOA}

The volatility of the organic aerosol can be calculated from changes in $f^{\text {sus }} \equiv C_{\mathrm{OA}}^{\text {sus }} / C_{\text {seed }}^{\text {sus }}$ measured by the AMS, comparing $f_{\mathrm{TD}}^{\text {sus }}\left(T_{\mathrm{TD}}\right)$, the organic fraction of the aerosol after it was sent through the thermodenuder at temperature $T_{\mathrm{TD}}$, to $f_{\text {bypass }}^{\text {sus }}\left(T_{\text {bypass }}\right)$, the organic fraction of the aerosol after it was sent through the bypass, maintained at a constant temperature $T_{\text {bypass }}$ (room temperature). The mass fraction remaining (MFR) after volatilization in the thermodenuder is given by:

$\operatorname{MFR}\left(T_{\mathrm{TD}}\right)=\frac{f_{\mathrm{TD}}^{\mathrm{sus}}\left(T_{\mathrm{TD}}\right)}{f_{\text {bypass }}^{\text {sus }}\left(T_{\text {bypass }}\right)}$

Using the organic fractions $f^{\text {sus }}$ rather than the total organic aerosol mass to calculate MFR removes the need for a wallloss correction and avoids the associated uncertainties.

\subsection{Parameterizing aerosol yields}

Even simple SOA systems involve 10's to 100's of chemical products, and often relatively small mass yields of aerosol are important. This means that the compounds contributing to SOA formation may be numerous and also relatively minor reaction products. Furthermore, they may evolve over time, and their physical properties, such as vapor pressures and activity coefficients, are usually not known. Because of this, we characterize SOA formation with an empirical approach known as the Volatility Basis Set (VBS), in which products are separated based on their most relevant property - volatility - given by $C^{*}$. Equation (2) suggests that $C^{*}$ is simply the organic aerosol mass concentration at which a given compound is found $50 \%$ in the gas phase and $50 \%$ in the particle phase. It is convenient to separate products into volatility bins that are regularly spaced by factors of 10 in $C^{*}$-space (Donahue et al., 2006). The exact set depends on the problem at hand, and here we shall consider 4 bins ranging from $1 \mu \mathrm{g} \mathrm{m}^{-3}$ to $1000 \mu \mathrm{g} \mathrm{m}^{-3}$, because that is the approximate range of SOA mass covered in these experiments. We can then describe an SOA forming reaction in terms of mass yields $\alpha_{i}$ of products $P_{i}$. The product yields $\alpha_{i}$ are related to the aerosol yield $Y$ by

$Y=\sum_{i} \alpha_{i} \xi_{i}$

where $\xi_{i}$ is the mass fraction of bin $i$ in the condensed phase, as given by Eq. (2). The simplest case is one in which a single reaction connects the precursor to first-generation products with yields $\alpha_{i}$ that do not change over time. The product concentrations $P_{i}$ are then just a simple product of the precursor consumption $\Delta C_{\text {prec }}$ :

$P_{i}=\alpha_{i} \Delta C_{\text {prec }}$ 


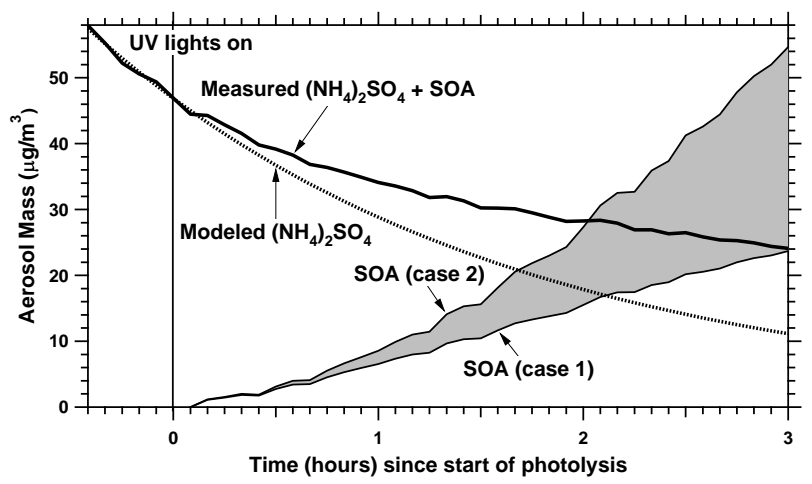

Fig. 2. Aerosol mass calculated from SMPS measurements for experiment 12 , showing the modeled decay of inorganic seed, the slower decay of measured mass, and the mass of organic aerosol formed assuming no wall condensation (case 1) and wall condensation without additional mass-transfer limitations (case 2). The shaded area represents the uncertainty in the wall loss correction.

An example is the ozone $+\alpha$-pinene system (Presto and Donahue, 2006). In this case, Odum et al. (1996) showed that one can simply observe the SOA mass yields as a function of SOA concentration in one or a succession of experiments, obtaining $Y\left(C_{\mathrm{OA}}\right)$ and invert these data using Eqs. (1) and (2) to obtain the $\alpha_{i}$. This can be accomplished via nonlinear least-squares fitting (Stanier et al., 2008).

However, when progressive oxidation (aging) occurs, as with $\mathrm{OH}$ oxidation experiments such as the ones presented here, the product distribution may not be constant, and the simple fit mentioned above may not be valid. The situation is more complicated when the aging is continuous, especially when the precursor is relatively non-reactive and the oxidation products are significantly more reactive, which is probably the case here. Several generations of products will emerge and change in concentration continuously over the course of an experiment. Here, we approximate basis-set parameters for this system for use in air-quality models until a more thorough treatment of these dynamic systems becomes available. These parameters do not capture the full dynamic evolution of the toluene SOA (the aging), but they do reasonably reproduce the chamber data.

\section{Results}

The increasing organic to ammonium sulfate ratio shown in Fig. 1 implies that organic mass is transferred to the suspended particles (those we measure with the AMS) throughout the experiment. The aerosol mass concentrations calculated from SMPS volume measurements for this experiment (Eqs. 9 and 10) are shown in Fig. 2. Time is referenced to the onset of photolysis $(t=0)$. The total suspended aerosol mass (black solid line) declines continuously due to wall losses, even as the organic to ammonium sulfate ratio

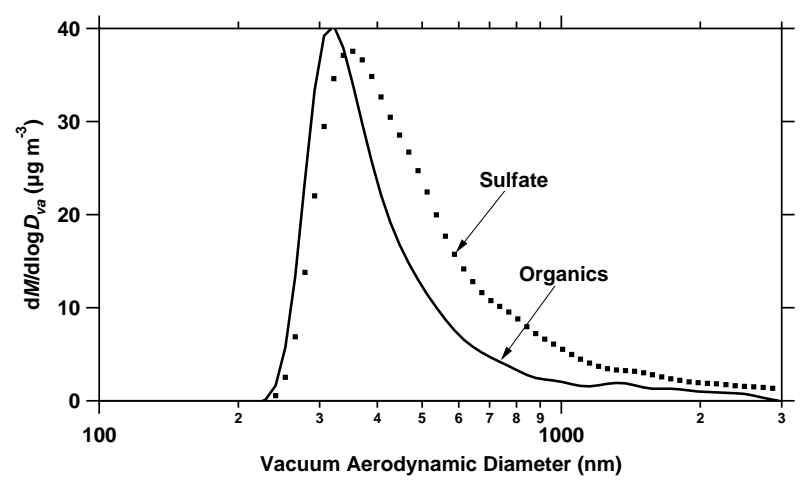

Fig. 3. AMS particle time-of-flight aerodynamic size distribution for experiment 12, averaged between 1 and $2 \mathrm{~h}$ after the onset of photolysis. The organic mass appears on the existing sulfate mode, though shifted to smaller sizes. This suggests that the SOA condenses onto the seed particles but does not form a perfect mixture with them.

increases. For $t<0$ the aerosol is entirely inorganic seed and its evolution is entirely due to wall losses. The modeled inorganic suspended aerosol mass (black dotted line) calculated from Eq. (8) thus tracks the total suspended mass $C_{\mathrm{OA}}^{\text {sus }}(t)$ for $t<0$. When the UV-lights are turned on, initiating toluene oxidation, the measured mass deviates from the modeled inorganic mass, consistent with net condensation of organic aerosol and $C_{\mathrm{OA}}^{\text {sus }}(t)>0$ (Eq. 9).

The suspended particles form a partial internal mixture: all particles consist of ammonium sulfate cores coated with toluene-derived SOA, but the organic to sulfate ratio is a function of the particle size. Three pieces of evidence confirm this. First, the particle size distribution measured by the SMPS remains monomodal as it grows after oxidation commences, consistent with the mass transfer of organic material to the pre-existing ammonium sulfate seed. The absence of a second particle mode suggests that nucleation does not occur to a measurable extent. Second, the apparent sulfate signal in the AMS rises after SOA condensation commences, consistent with an SOA coating of the inorganic seed, leading to increased particle collection efficiency. Third, the organics clearly appear on the existing sulfate mode, albeit shifted somewhat toward smaller sizes. This is shown in Fig. 3, which plots the AMS particle time-of-flight aerodynamic size distribution for experiment 12 averaged between 1 and $2 \mathrm{~h}$ after the onset of photolysis. These time-of-flight spectra are consistent with condensational coating of the inorganic seeds, which will scale with inorganic surface area and not mass. Because the organics appear to be coating the sulfate, and not mixing with it, this also supports the hypothesis that the seed particles have little effect on the SOA mass yields, other than to prevent the "induction effect" caused by wall condensation before new particle formation sometimes observed in "nucleation" (non-seeded) experiments (Kroll et al., 2007; Pathak et al., 2007). 


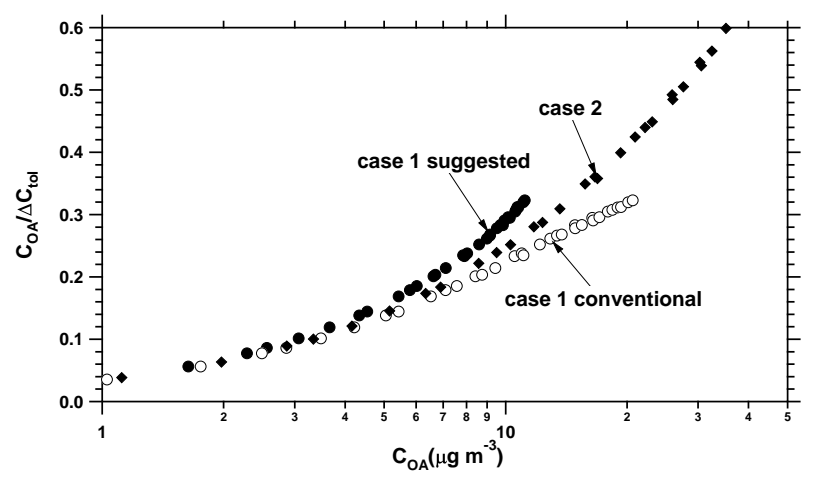

Fig. 4. Aerosol yield for experiment 7 as a function of total aerosol concentration, $C_{\mathrm{OA}}$, calculated from SMPS volume measurements, assuming no interaction between vapors and particles deposited on the walls (case 1, circles) and facile interaction between vapors and particles deposited on the walls (case 2, solid diamonds). Two different conventions are used for the case 1 aerosol mass calculation: using total organic mass on the $\mathrm{x}$-axis (open circles, conventional method but inconsistent) and using only suspended organic mass on the $\mathrm{x}$-axis (solid circles, suggested to be more consistent).

The offset in the aerodynamic size distributions of organic and inorganic material shown in Fig. 3 suggests that $f^{\text {sus }}$, the fraction of suspended organic mass to suspended seed mass, does depend on particle size. The assumption that $k_{w}$ is the same for ammonium sulfate and organics may thus introduce some error in the mass yield calculations. If particle wall loss is dependent on particle size, ammonium sulfate and organics will be lost at slightly different rates. The wall loss of organics is probably higher than that of ammonium sulfate since the aerodynamic size distribution of the organics is shifted to smaller sizes relative to that of ammonium sulfate, and smaller particles in this size range are expected to have higher wall-loss rates. This introduces a negative bias in the organic aerosol mass yield calculations. Given that the difference in the mode diameters was less than $0.1 \mu \mathrm{m}$ (aerodynamic diameter; the difference is smaller in mobility diameter) and that the depositional loss curve is relatively flat in this size region (Pierce et al., 2008), we estimate that the error introduced by assuming a common $k_{w}$ is only a few percent.

\subsection{Quantifying SOA production}

Assumptions regarding the wall-loss correction represent the largest uncertainty for quantifying the SOA production. To illustrate this uncertainty, the two extreme estimates of the wall-loss corrected mass are shown in Fig. 2, where the uncertainty in the wall correction is represented by the area between these two curves. The area increases throughout the experiment as the uncertainty due to the wall-condensation correction increases. Because of this increasing uncertainty with time, we focus on yield data for the first $3 \mathrm{~h}$ of each experiment.
Using the wall-loss corrected masses presented in Fig. 2 and the decay of toluene measured by the PTR-MS (not shown), we can calculate the fractional aerosol mass yield for these two bounding cases (Fig. 4). When presented as a function of $C_{\mathrm{OA}}$, the uncertainty resulting from the wall correction is smaller. This is because neglecting wall condensation results in smaller aerosol yields (y-axis), but also in smaller $C_{\mathrm{OA}}$ (x-axis). This is reassuring since traditional air-quality models as well as newer formulations using the basis-set approach (Donahue et al., 2006) essentially model the formation of aerosol as a function of the total organic aerosol concentration. In addition, the uncertainty is even smaller for $C_{\mathrm{OA}}<10 \mu \mathrm{g} \mathrm{m}^{-3}$, which is the more atmospherically relevant range of organic aerosol concentrations.

The yield data for the case of no wall condensation (case 1) are presented in two different ways in Fig. 4. One (open circles) is consistent with previous studies: the total organic aerosol mass $C_{\mathrm{OA}}(t)=C_{\mathrm{OA}}^{\text {sus }}(t)+C_{\mathrm{OA}}^{\text {wall }}(t)$ is used for the aerosol mass yield calculations (Eq. 1) and as the dependent variable (x-axis). However, there is a logical flaw in this representation: neglecting wall condensation assumes that there are no interactions between organic vapors in suspension and the organic vapors deposited on the walls. Therefore, while $C_{\mathrm{OA}}^{\text {wall }}(t)$ describes organic-aerosol mass that was formed and should therefore be included in the calculation of mass yield, it is assumed to not affect the partitioning behavior in the system and should therefore not be included on the $\mathrm{x}$-axis. A consistent representation of this case would plot $Y=\frac{C_{\mathrm{OA}}^{\mathrm{sus}}+C_{\mathrm{OA}}^{\text {wall }}}{\Delta C_{\mathrm{OCC}}}$ as a function of $C_{\mathrm{OA}}^{\mathrm{sus}}$. Plotting the case 1 mass yield data in this way for experiment 7 results in case 1 yields (no wall condensation, solid circles) that are higher than case 2 yields (wall-vapor equilibrium, solid diamonds). Note from Fig. 4 that the difference in either of the case 1 models and the case 2 model is small. The remaining analysis will utilize the case 2 aerosol mass yields, which are not only more consistent with equilibrium thermodynamics but also with earlier studies (Weitkamp et al., 2007).

Figure 5 compares the aerosol mass yields in experiment 7 , calculated from the SMPS data and the AMS data, assuming wall-vapor equilibrium (Eq. 10). Note that these measurements agree very well for this experiment. However, the agreement between yields calculated from SMPS data and those calculated from AMS data is not always this good. The agreement in the yields as a function of time calculated from both instruments is usually within $50 \%$; the agreement is better for yields as a function of $C_{\mathrm{OA}}$. However, in low-mass experiments in which total organic aerosol loading and $f^{\text {sus }}$ are small, SMPS yields cannot be calculated reliably because they rely on calculating a small difference. In this system, it is not advisable to use SMPS yield data when, after one hour of photo-oxidation, $C_{\mathrm{OA}}^{\text {sus }}$ is less than $10 \mu \mathrm{g} \mathrm{m}^{-3}$ and $f^{\text {sus }}$ is less than 0.3. In general, and particularly for smaller organic aerosol loadings, the precision of the AMS data is expected to be superior since the mass-yield calculations from AMS 


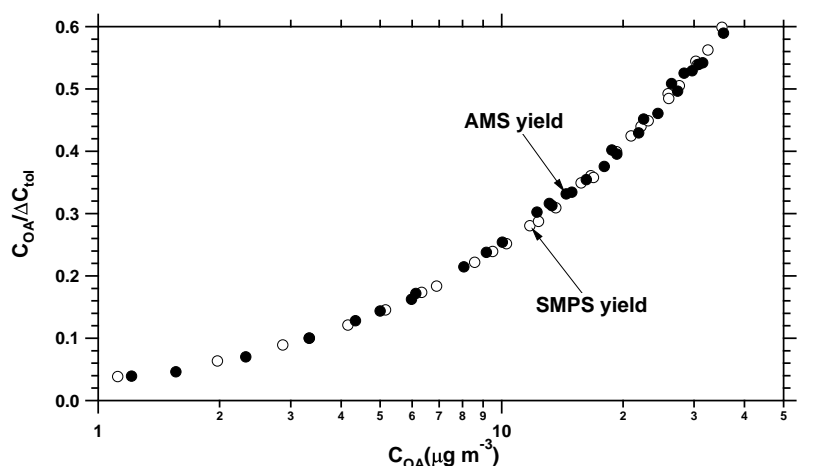

Fig. 5. Aerosol yields calculated from AMS data (solid circles) and SMPS data (open circles) agree well for experiment 7. Both yield calculations assume facile interaction between the vapors and the particles deposited on the wall (case 2).

data are based on the directly measured organic to sulfate mass ratio, while the calculations from SMPS data rely on computing the small difference between two number size distribution measurements. Furthermore, the mass yields calculated from the SMPS are strongly dependent on the measured particle wall deposition constant $k_{w}(t)$, which introduces additional uncertainty and potential for error. Consider, for example, experiments 11 and 12, which were run at very similar conditions and are hence expected to give similar results (Fig. 6). The AMS yields calculated from these two experiments agree well; however, the SMPS yields do not agree well, especially in the later stages of the experiment. This difference might be due to the estimated wall deposition constant: $k_{w}$ of experiment 11 increased by almost a factor of 2 during the experiment, while $k_{w}$ of experiment 12 changed by less than $10 \%$, which is more consistent with other experiments. This high measured $k_{w}$ in experiment 11 leads to an overestimation of the wall loss and therefore an overestimation of the organic aerosol formed. Considering the superior precision of the AMS data for this system, we use the aerosol mass yields calculated from the AMS for the remaining analysis. Comparing experiments conducted under similar experimental conditions in this work (experiments 11 and 12) and consistent with previous work (Pathak et al., 2007), we estimate that our experimental error in aerosol mass yields is $\pm 10 \%$.

\subsection{Dependence on experimental conditions}

The yields measured in this study clearly depend on experimental conditions. In this section we shall compare experiments where a single parameter (e.g. temperature) varies while other conditions remain the same or similar. We are thus experimentally determining partial derivatives of this complex yield surface.

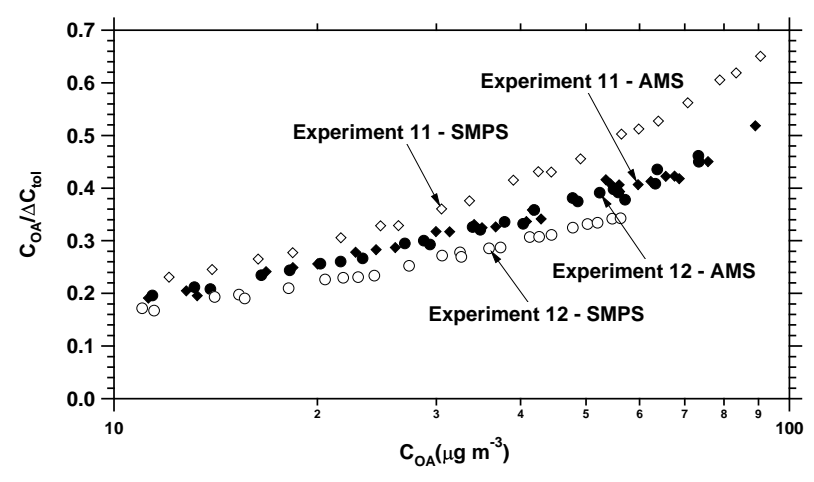

Fig. 6. Reproducibility of experiments is better for AMS data (solid symbols) than for SMPS data (open symbols). Experiments 11 (diamonds) and 12 (circles) were conducted under very similar conditions. All yield calculations assume facile interaction between vapors and particles deposited on the walls (case 2).

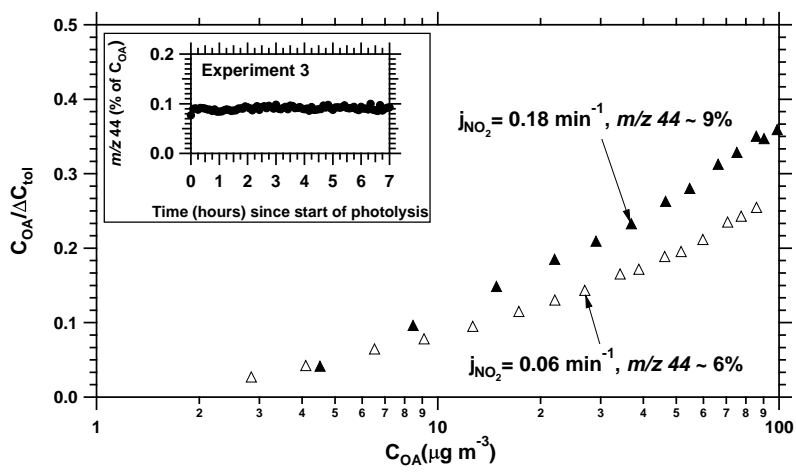

Fig. 7. Effect of UV intensity on aerosol mass yield for two high$\mathrm{NO}_{\mathrm{x}}$ experiments. The yield in experiment 3 (high UV, solid triangles) is higher than the yield in experiment $1(1 / 3 \mathrm{UV}$, open triangles). Inset: $\% \mathrm{~m} / \mathrm{z}, 44$ does not change over the course of a long photo-oxidation experiment such as experiment 3 .

Figure 7 shows the effect of the UV intensity on the aerosol yield under high- $\mathrm{NO}_{\mathrm{x}}$ conditions: when all UV lights are used (experiment 3 ) the aerosol mass yield is higher than when one third of the UV lights are used (experiment 1). The $\mathrm{NO}_{2}$ photolysis rate, measured in separate experiments, was $0.18 \mathrm{~min}^{-1}$ when all UV lights were used and $0.06 \mathrm{~min}^{-1}$ when one third of the UV lights were used, thus the photolysis rate is proportional to the number of UV lights used, as expected. Even though less SOA is formed under the less active photochemical conditions (fewer UV lights used), the $\mathrm{OH}$ levels (based on the observed toluene decay rate) are not significantly lower at lower UV intensity. Other factors (photolysis of organic hydroperoxide intermediates, $\mathrm{HO}_{2}$ levels) may drive these changes. What is clear is that the toluene SOA system is sensitive to UV intensity. The photolysis rate of $0.18 \mathrm{~min}^{-1}$ is more similar to atmospheric conditions $\left(0.53 \mathrm{~min}^{-1}\right.$ at solar zenith angle $0^{\circ}$ and $0.21 \mathrm{~min}^{-1}$ at solar 

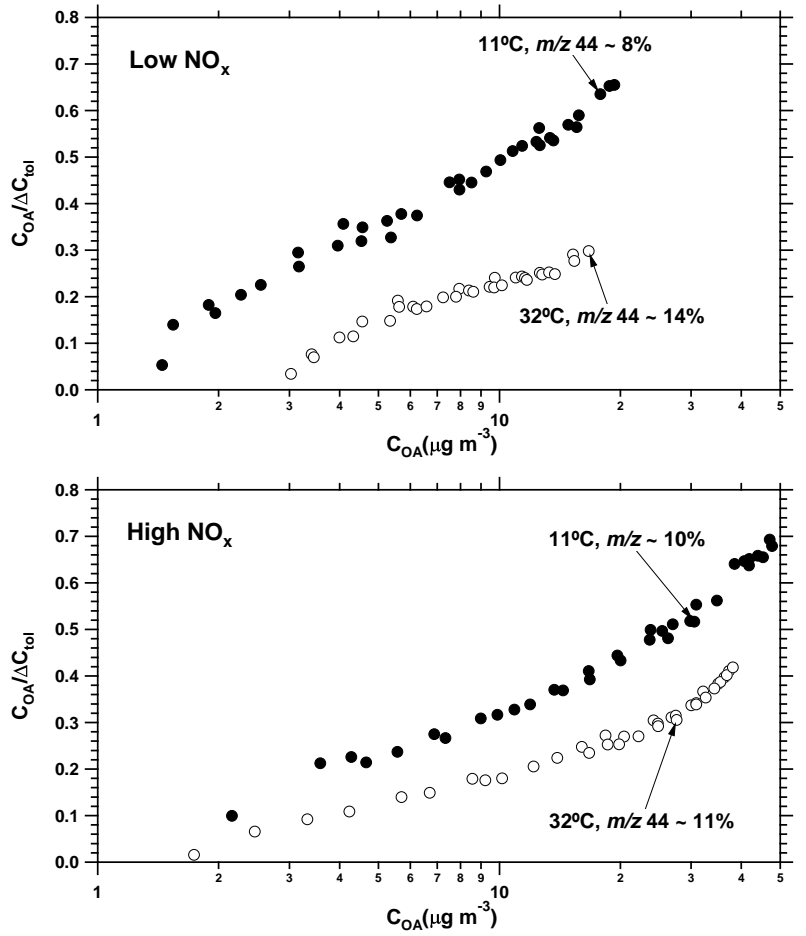

Fig. 8. Temperature effect on aerosol yield for low- $\mathrm{NO}_{\mathrm{x}}$ (top panel, Expt. 9: $11^{\circ} \mathrm{C}$, Expt. 10: $32^{\circ} \mathrm{C}$ ) and high- $\mathrm{NO}_{\mathrm{x}}$ (bottom panel, Expt. 5: $11^{\circ} \mathrm{C}$, Expt. 6: $32^{\circ} \mathrm{C}$ ) experiments. In both cases yields are significantly higher at lower temperatures.

zenith angle $70^{\circ}$, Carter et al., 2005); hence all UV lights were used in experiments 2 to 13 . A summary of the aerosol mass yields at $10 \mu \mathrm{g} \mathrm{m}^{-3}$ and $20 \mu \mathrm{g} \mathrm{m}^{-3}$ measured for the different experiments is presented in Table 1 .

Figure 8 compares experiments conducted at different temperatures. The aerosol yield data from experiments 9 and 10 show the temperature dependence under low- $\mathrm{NO}_{\mathrm{x}}$ conditions: at $10 \mu \mathrm{g} \mathrm{m}^{-3}$ organic aerosol loading aerosol yields are $120 \%$ higher at $11^{\circ} \mathrm{C}$ (experiment 9) than at $32^{\circ} \mathrm{C}$ (experiment 10). Experiments 5 and 6 show the temperature dependence under high- $\mathrm{NO}_{\mathrm{x}}$ conditions: at $10 \mu \mathrm{g} \mathrm{m}^{-3}$ organic aerosol loading, aerosol yields are $80 \%$ higher at $11^{\circ} \mathrm{C}$ (experiment 5) than at $32^{\circ} \mathrm{C}$ (experiment 6). Aerosol yields are higher at lower temperature under both low- $\mathrm{NO}_{\mathrm{x}}$ and high- $\mathrm{NO}_{\mathrm{x}}$ conditions. This is consistent with equilibrium partitioning of semi-volatile products.

Figure 9 compares the yields at different $\mathrm{NO}_{\mathrm{x}}$ levels. At $11^{\circ} \mathrm{C}$ (top panel), the aerosol mass yield at $10 \mu \mathrm{g} \mathrm{m}^{-3}$ organic aerosol loading is $50 \%$ higher in experiment 9 (low $\mathrm{NO}_{\mathrm{x}}$ ) than in experiment $5\left(\right.$ high $\mathrm{NO}_{\mathrm{x}}$ ); at $20^{\circ} \mathrm{C}$ (not shown), the aerosol mass yield at $10 \mu \mathrm{g} \mathrm{m}^{-3}$ is $30 \%$ higher in experiment 7 (low $\mathrm{NO}_{\mathrm{x}}$ ) than in experiment $2\left(\right.$ high $\left.\mathrm{NO}_{\mathrm{x}}\right)$; at $32^{\circ} \mathrm{C}$ (bottom panel), the aerosol mass yield at $10 \mu \mathrm{g} \mathrm{m}^{-3}$ is $20 \%$ higher in experiment $10\left(\right.$ low $\left.\mathrm{NO}_{\mathrm{x}}\right)$ than in experiment 6 (high $\mathrm{NO}_{\mathrm{x}}$ ). Thus, at all temperatures investigated,
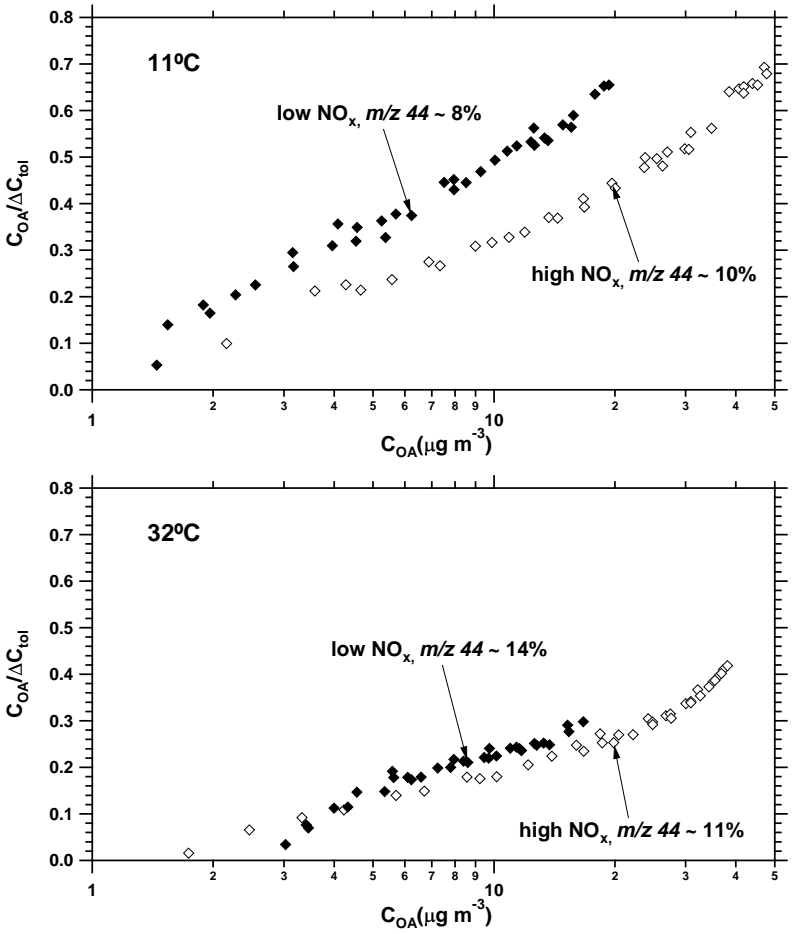

Fig. 9. $\mathrm{NO}_{\mathrm{x}}$ effect on aerosol yield at $11^{\circ} \mathrm{C}$ (top panel, Expt. 9: low $\mathrm{NO}_{\mathrm{x}}$, Expt. 5: high $\mathrm{NO}_{\mathrm{x}}$ ) and $32^{\circ} \mathrm{C}$ (bottom panel, Expt. 10: low $\mathrm{NO}_{\mathrm{x}}$, Expt. 6: high $\mathrm{NO}_{\mathrm{x}}$ ). Yields from low- $\mathrm{NO}_{\mathrm{x}}$ experiments (solid diamonds) are higher than yields from high- $\mathrm{NO}_{\mathrm{x}}$ experiments (open diamonds).

aerosol yields are lower under high- $\mathrm{NO}_{\mathrm{x}}$ conditions, suggesting that the products formed under high- $\mathrm{NO}_{\mathrm{x}}$ conditions may be more volatile than those formed under low- $\mathrm{NO}_{\mathrm{x}}$ conditions. The $\mathrm{NO}_{\mathrm{x}}$ level appears to have a smaller effect at higher temperatures.

\subsection{Composition of organic aerosol - extent of oxidation}

The oxidation state of the organic aerosol, presented as the percent of the organic signal due to mass at $m / z 44$ (henceforth referred to as \%44) is presented in the inset of Fig. 7 for a long toluene photo-oxidation experiment (experiment 3). Note that the oxidation state of the aerosol does not change appreciably throughout the experiment. The same was observed in most other experiments presented in this study. In experiments 1, 2 and 6,\%44 increased slightly during the first hour of photo-oxidation; but after the first hour, \%44 remained constant in all experiments. This is in contrast to "simple" SOA cases such as terpenes + ozone (Zhang et al., 2006; Grieshop et al., 2007), where the oxidation state decreases markedly as $C_{\mathrm{OA}}$ rises. Those simple cases are consistent with the hypothesis that terpene ozonolysis produces a stable distribution of products in which the more oxidized compounds tend to have lower saturation concentrations; in 
that case increased $C_{\mathrm{OA}}$ will result in a reduced $\% 44$. Conversely, in oxidized systems that are already dominated by low-volatility material (for example diesel emission), \%44 increases with $C_{\mathrm{OA}}$ (Sage et al., 2007). The signature of a fixed product distribution (i.e. ozone + terpenes) is thus often a decrease in $\% 44$ with a large increase in $C_{\mathrm{OA}}$ while the signature of chemical aging (i.e. evaporated primary emissions) is a sharp increase in \%44 with a modest increase in $C_{\mathrm{OA}}$. It appears that the toluene system may be a mixture of these two phenomena.

Even though \%44 does not change after the first hour of an experiment, there is significant variability in \%44 between experiments, as noted in Figs. 7-9 and summarized in Table 1 . The oxidation state of the aerosol, represented by $\% 44$, is higher for experiments conducted at higher temperature (Experiment 6 vs. 5 and experiment 10 vs. 9). This is consistent with the notion that less oxidized compounds (lower $\% 44)$ have higher volatility, resulting in less net condensation of these products to the aerosol phase. There is no clear trend in \%44 in the low- versus high- $\mathrm{NO}_{\mathrm{x}}$ experiments of this study. This is not inconsistent with the mass-yield data since lower volatility (and therefore higher mass yields) can be caused by increased branching, not just increased oxidation of the aerosol products. Aerosol formed under higher photochemical activity (more UV lights, experiment 3 ) is more oxidized (higher \%44) than aerosol formed under lower photochemical activity (experiment 1 ). This variation in $\% 44$ between experiments indicates that the product distribution of SOA formed from toluene photo-oxidation may depend on experimental conditions. The range of different $\% 44$ measured in these experiments (6\% to $14 \%$ ), corresponds to an approximate range in $\mathrm{O} / \mathrm{C}$ of 0.3 to 0.6 using Eq. (11), and they are within the range of $\% 44$ observed in the ambient atmosphere ( 3\%-25\%, Aiken et al., 2008).

\subsection{Volatility of SOA}

Volatility measurements show that the aerosol formed under low- and high- $\mathrm{NO}_{\mathrm{x}}$ conditions is clearly semi-volatile. Under high- $\mathrm{NO}_{\mathrm{x}}$ conditions, approximately $60 \%$ of the organicaerosol mass evaporates at $38^{\circ} \mathrm{C}$ and $16.5 \mathrm{~s}$ centerline residence time (experiment 13). Under low- $\mathrm{NO}_{\mathrm{x}}$ conditions approximately $55 \%$ of the organic aerosol mass evaporates at $39^{\circ} \mathrm{C}$ and $16.5 \mathrm{~s}$ residence time (experiment 8 ) and more than $90 \%$ of the organic aerosol mass evaporates at $52^{\circ} \mathrm{C}$. This behavior is inconsistent with the suggestion of $\mathrm{Ng}$ et al. (2007) that the toluene SOA under low- $\mathrm{NO}_{\mathrm{x}}$ conditions could be described by a single, non-volatile product. This illustrates the difficulty of interpreting yield data for this complex system. The observation that the aerosol is semi-volatile is consistent with the presence of a yield-dependence on temperature. The product distribution of the SOA seems to change upon heating, as \%44 is higher in the aerosol after the thermodenuder than in the aerosol after the bypass line. In experiment $8, \% 44$ was about $20 \%$ higher in the thermodenuder
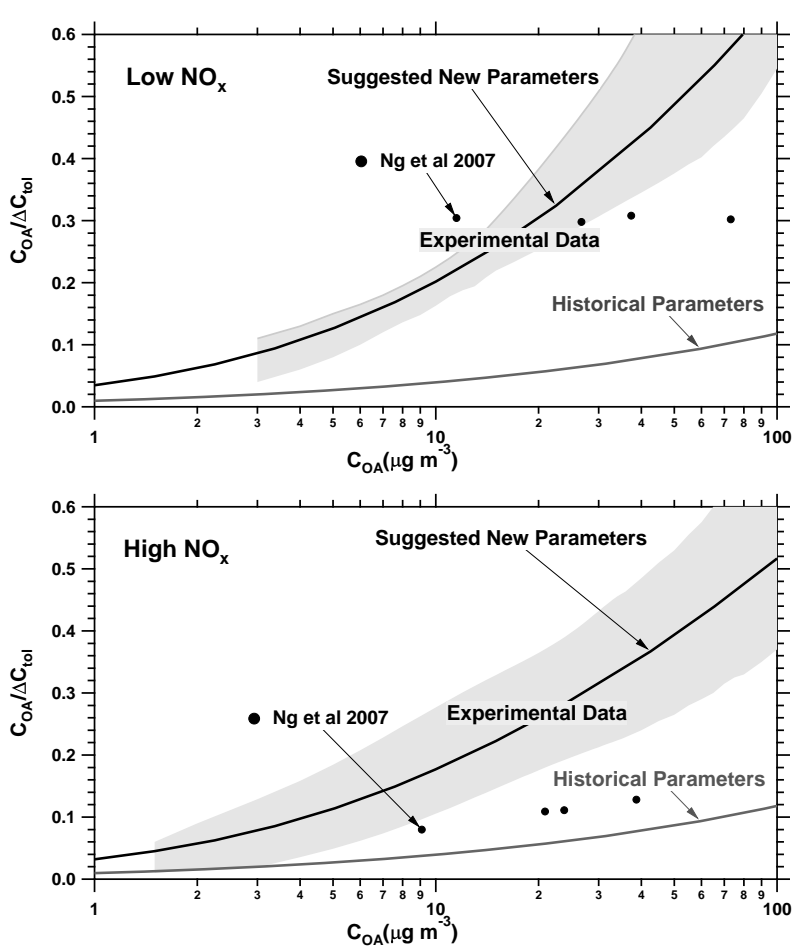

Fig. 10. Summary of experimental data at $20^{\circ} \mathrm{C}$ under low- $-\mathrm{NO}_{\mathrm{x}}$ (top panel) and high- $\mathrm{NO}_{\mathrm{x}}$ (bottom panel) conditions. The yield parameters consistent with these data (suggested new parameters) are much higher than those currently used in air-quality models (historical parameters). Historical organic aerosol yields (y-axis) and total organic aerosol concentration (x-axis) used for the historical yield curve were multiplied by an organic aerosol density of $1.4 \mathrm{~g} \mathrm{~cm}^{-3}$ for better comparison with the experimental data, which were derived from direct mass measurements.

aerosol than in the bypass aerosol when the thermodenuder temperature was $52^{\circ} \mathrm{C}$, and about $10 \%$ higher when the temperature was $39^{\circ} \mathrm{C}$. We plan to characterize the volatility of organic aerosol formed from toluene photo-oxidation more thoroughly in future work.

\subsection{Comparison to previous studies}

The yields observed in these experiments are higher than those reported previously. Potential explanations for differences between older studies and the more recent studies were addressed in Sect. 1.1. Here we shall focus on the relatively smaller differences between the present study and the recent studies of $\mathrm{Ng}$ et al. (2007, solid circles).

The top panel of Fig. 10 compares the results from our low- $\mathrm{NO}_{\mathrm{x}}$ experiments conducted at $20^{\circ} \mathrm{C}$ and the low- $\mathrm{NO}_{\mathrm{x}}$ experiments conducted by $\mathrm{Ng}$ et al. (2007) at similar temperatures. Quantitatively, the results from these two studies agree reasonably well. However, the qualitative behavior of aerosol yield with organic aerosol concentration is different: the yields observed in this study increase steadily with 
Table 2. SOA mass yields using a four-product volatility basis set.

\begin{tabular}{lrrrr}
\hline $\begin{array}{l}\text { Saturation } \\
\text { concentration } \\
\left(\mu \mathrm{g} \mathrm{m}^{-3}\right)\end{array}$ & 1 & 10 & 100 & 1000 \\
\hline Historical $^{*}$ & 0.01 & 0.03 & 0.075 & 0.25 \\
Low NO & \\
High $_{\mathrm{NO}}, 20^{\circ} \mathrm{C}$ & 0.01 & 0.24 & 0.7 & 0.7 \\
\hline
\end{tabular}

* Historical parameters assuming OA density of $1 \mathrm{~g} \mathrm{~cm}^{-3}$ (Lane et al., 2007).

aerosol concentration while the yields observed by $\mathrm{Ng}$ et al. (2007) are constant.

The bottom panel of Fig. 10 compares the results from this study's high- $\mathrm{NO}_{\mathrm{x}}$ experiments conducted at $20^{\circ} \mathrm{C}$ and the high- $\mathrm{NO}_{\mathrm{x}}$ experiments conducted by $\mathrm{Ng}$ et al. (2007) under similar conditions. The yields reported in this study are higher than those reported in the previous study. One difference between these experiments is that, in the present study, $\mathrm{NO}_{\mathrm{x}}$ is present mostly as $\mathrm{NO}_{2}$ since all $\mathrm{NO}$ is quickly converted to $\mathrm{NO}_{2}$ in a few minutes after the UV lights are turned on. Therefore, while the experiments are conducted under high- $\mathrm{NO}_{\mathrm{x}}$ conditions, the conditions are low-NO for most of the time, which may affect gas-phase chemistry. A mixture of $\mathrm{NO}$ and $\mathrm{NO}_{2}$ more closely resembles typical atmospheric conditions; therefore, the experiments by $\mathrm{Ng}$ et al. (2007) may capture this aspect of the system better. A further difference is that the average temperatures in the experiments of $\mathrm{Ng}$ et al. (2007) were slightly higher and less controlled than in the experiments reported here. Finally, the yields reported by the previous study were not corrected for the condensation of organic vapors onto wall particles. Applying this correction is expected to result in higher organic aerosol yields. Aerosol mass yields appear to be highly sensitive to experimental conditions as well as corrections of the data for losses to the chamber walls.

\subsection{Aerosol yield parameterizations}

Volatility basis set (VBS) parameters consistent with the data at $20^{\circ} \mathrm{C}$ are presented in Table 2 for low- $\mathrm{NO}_{\mathrm{x}}$ and high- $\mathrm{NO}_{\mathrm{x}}$ conditions, and yield curves resulting from these parameterizations are shown in Fig. 10. These basis-set parameters do not account for the dynamic nature of the system. A new framework and application for dynamic basis-set parameters will be presented in a future publication.

Table 2 also records "historical parameters", the parameters currently used in air-quality models for small aromatic anthropogenic VOCs such as toluene (Lane et al., 2008), and the resulting VBS yield curves are shown in Fig. 10. Note that the parameters consistent with the data presented in this paper far exceed the historical parameters. This means that air-quality models employing these new parameters will predict significantly more anthropogenic SOA, partially closing the mass gap between model predictions and ambient observations (Volkamer et al., 2006).

\section{Conclusions}

The SOA yields from the photo-oxidation of toluene are higher than previously reported values. Though the SOA yields show variability consistent with complex toluene photochemistry, in all cases they are significantly higher than current model parameterizations predict. The main differences between this study and previous studies which reported lower yields are: first, experimental conditions such as temperature, the levels of $\mathrm{NO}$ and $\mathrm{NO}_{2}$ and the amount of UV lights used, which affect measured SOA mass yields. Second, the use of the AMS to calculate SOA mass yields. Yields calculated from the SMPS are frequently not reliable, especially when organic aerosol loading and/or the ratio of suspended organic mass to inorganic mass is low. And third, the correction for the condensation of organic vapors to the walls of the chamber. We are the first to apply this correction, which is more important in this dynamic, slowly reacting system. The correction is also more important for experiments conducted without seed aerosol, and experiments conducted in smaller environmental chambers. We suggest yield parameters consistent with these data which should be used in air-quality models as an approximation of a more thorough treatment of this dynamic system.

Acknowledgements. This research was supported by the EPA STAR program through the National Center for Environmental Research (NCER). This paper has not been subject to EPA's required peer and policy review, and therefore does not necessarily reflect the views of the Agency. No official endorsement should be inferred. Lea Hildebrandt was supported by a National Science Foundation Graduate Research Fellowship.

Edited by: G. McFiggans

\section{References}

Aiken, A. C., DeCarlo, P. F., Kroll, J. H., Worsnop, D. R., Huffman, J. A., Docherty, K., Ulbrich, I. M., Mohr, C., Kimmel, J. R., Sueper, D., Sun, Y., Zhang, Q., Trimborn, A. M., Northway, M. J., Ziemann, P. J., Canagaratna, M. R., Alfarra, M. R., Prevot, A. S. H., Dommen, J., Duplissy, J., Metzger, A., Baltensperger, U., and Jimenez, J. L.: O/C and OM/OC ratios of primary, secondary, and ambient organic aerosols with high resolution timeof-flight aerosol mass spectrometry, Environ. Sci. Technol., 42, 4478-4485, 2008.

Allan, J. D., Delia, A. E., Coe, H., Bower, K. N., Alfarra, M. R., Jimenez, J. L., Middlebrook, A. M., Drewnick, F., Onasch, T. B., Canagaratna, M. R., Jayne, J. T., and Worsnop, D. R.: A generalised method for the extraction of chemically resolved mass 
spectra from aerodyne aerosol mass spectrometer data, J. Aerosol Sci., 35, 909-922, 2004.

An, W. J., Pathak, R. K., Lee, B.-H., and Pandis, S. N.: Aerosol volatility measurement using an improved thermodenuder: Application to secondary organic aerosol, J. Aerosol Sci., 38, 305314, 2007.

Carter, W. P. L., Cocker, D. R., Fitz, D. R., Malkina, I. L., Bumiller, K., Sauer, C. G., Pisano, J. T., Bufalino, C., and Song, C.: A new environmental chamber for evaluation of gas-phase chemical mechanisms and secondary aerosol formation, Atmos. Environ., 39, 7768-7788, 2005.

Crump, J. G. and Seinfeld, J. H.: Turbulent Deposition and Gravitational Sedimentation of an Aerosol in a Vessel of Arbitrary Shape, J. Aerosol Sci., 12, 405-415, 1981.

Davidson, C. I., Phalen, R. F., and Solomon, P. A.: Airborne particulate matter and human health: A review, Aerosol Sci. Tech., 39, 737-749, 2005.

de Gouw, J. A., Goldan, P. D., Warneke, C., Kuster, W. C., Roberts, J. M., Marchewka, M., Bertman, S. B., Pszenny, A. A. P., and Keene, W. C.: Validation of proton transfer reaction-mass spectrometry (PTR-MS) measurements of gas-phase organic compounds in the atmosphere during the New England Air Quality Study (NEAQS) in 2002, J. Geophys. Res.- Atmos., 108, 4682, doi:10.1029/2003jd003863, 2003.

Dockery, D. W., Pope, C. A., Xu, X. P., Spengler, J. D., Ware, J. H., Fay, M. E., Ferris, B. G., and Speizer, F. E.: An association between air-pollution and mortality in 6 United-States cities, New Engl. J. Med., 329, 1753-1759, 1993.

Donahue, N. M., Robinson, A. L., Stanier, C. O., and Pandis, S. N.: Coupled partitioning, dilution, and chemical aging of semivolatile organics, Environ. Sci. Technol., 40, 2635-2643, 2006.

Edney, E. O., Driscoll, D. J., Speer, R. E., Weathers, W. S., Kleindienst, T. E., Li, W., and Smith, D. F.: Impact of aerosol liquid water on secondary organic aerosol yields of irradiated toluene/propylene/ $\mathrm{NO}_{\mathrm{x}} /\left(\mathrm{NH}_{4}\right)_{2} \mathrm{SO}_{4} /$ air mixtures, Atmos. Environ., 34, 3907-3919, 2000.

Forstner, H. J. L.: Aerosol Formation from Atmospheric Hydrocarbon Photooxidation, Doctor of Philosophy, Chemical Engineering, California Institute of Technology, Pasadena, USA, 381 pp., 1996.

Goldstein, A. H. and Galbally, I. E.: Known and unexplored organic constituents in the Earth's atmosphere, Environ. Sci. Technol., 41, 1515-1521, 2007.

Grieshop, A. P., Donahue, N. M., and Robinson, A. L.: Is the gas-particle partitioning in alpha-pinene secondary organic aerosol reversible?, Geophys. Res. Lett., 34, L14810, doi:10.1029/2007g1029987, 2007.

Hennigan, C. J., Bergin, M. H., Dibb, J. E., and Weber, R. J.: Enhanced secondary organic aerosol formation due to water uptake by fine particles, Geophys. Res. Lett., 35, L18801, doi:10.1029/2008g1035046, 2008.

Hurley, M. D., Sokolov, O., Wallington, T. J., Takekawa, H., Karasawa, M., Klotz, B., Barnes, I., and Becker, K. H.: Organic aerosol formation during the atmospheric degradation of toluene, Environ. Sci. Technol., 35, 1358-1366, 2001.

IPCC: Climate Change 2007 - The Physical Science Basis. Contribution of Working Group I to the Fourth Assessment Report of the IPCC, 2007.
Izumi, K. and Fukuyama, T.: Photochemical aerosol formation from aromatic-hydrocarbons in the presence of $\mathrm{NO}_{\mathrm{x}}$, Atmos. Environ. A-Gen., 24, 1433-1441, 1990.

Jayne, J. T., Leard, D. C., Zhang, X. F., Davidovits, P., Smith, K. A., Kolb, C. E., and Worsnop, D. R.: Development of an aerosol mass spectrometer for size and composition analysis of submicron particles, Aerosol Sci. Tech., 33, 49-70, 2000.

Jimenez, J. L., Jayne, J. T., Shi, Q., Kolb, C. E., Worsnop, D. R., Yourshaw, I., Seinfeld, J. H., Flagan, R. C., Zhang, X., Smith, K. A., Morris, J. W., and Davidovits, P.: Ambient aerosol sampling using the Aerodyne Aerosol Mass Spectrometer, J. Geophys. Res.- Atmos., 108, 8425-8437, 2003.

Kanakidou, M., Seinfeld, J. H., Pandis, S. N., Barnes, I., Dentener, F. J., Facchini, M. C., Van Dingenen, R., Ervens, B., Nenes, A., Nielsen, C. J., Swietlicki, E., Putaud, J. P., Balkanski, Y., Fuzzi, S., Horth, J., Moortgat, G. K., Winterhalter, R., Myhre, C. E. L., Tsigaridis, K., Vignati, E., Stephanou, E. G., and Wilson, J.: Organic aerosol and global climate modelling: a review, Atmos. Chem. Phys., 5, 1053-1123, 2005, http://www.atmos-chem-phys.net/5/1053/2005/.

Karydis, V. A., Tsimpidi, A. P., and Pandis, S. N.: Evaluation of a three-dimensional chemical transport model (PMCAMx) in the eastern United States for all four seasons, J. Geophys. Res.Atmos., 112, D14211, doi:10.1029/2006jd007890, 2007.

Kleindienst, T. E., Smith, D. F., Li, W., Edney, E. O., Driscoll, D. J., Speer, R. E., and Weathers, W. S.: Secondary organic aerosol formation from the oxidation of aromatic hydrocarbons in the presence of dry submicron ammonium sulfate aerosol, Atmos. Environ., 33, 3669-3681, 1999.

Kleindienst, T. E., Conver, T. S., McIver, C. D., and Edney, E. O.: Determination of secondary organic aerosol products from the photooxidation of toluene and their implications in ambient $\mathrm{PM}_{2.5}$, J. Atmos. Chem., 47, 79-100, 2004.

Koo, B. Y., Ansari, A. S., and Pandis, S. N.: Integrated approaches to modeling the organic and inorganic atmospheric aerosol components, Atmos. Environ., 37, 4757-4768, 2003.

Kroll, J. H., Chan, A. W. H., Ng, N. L., Flagan, R. C., and Seinfeld, J. H.: Reactions of semivolatile organics and their effects on secondary organic aerosol formation, Environ. Sci. Technol., 41, 3545-3550, 2007.

LADCO - The Lake Michigan Air Directors Consortium: Midwest Regional Planning Organization: Base E Modeling Inventory, online available at: www.ladco.org, 1999.

Lane, T. E., Donahue, N. M., and Pandis, S. N.: Simulating secondary organic aerosol formation using the volatility basis-set approach in a chemical transport model, Atmos. Environ., 42, 7439-7451, doi:10.1016/j.atmosenv.2008.06.026, 2008.

McMurry, P. H. and Rader, D. J.: Aerosol wall losses in electrically charged chambers, Aerosol Sci. Tech., 4, 249-268, 1985.

Ng, N. L., Kroll, J. H., Chan, A. W. H., Chhabra, P. S., Flagan, R. C., and Seinfeld, J. H.: Secondary organic aerosol formation from m-xylene, toluene, and benzene, Atmos. Chem. Phys., 7, 3909-3922, 2007, http://www.atmos-chem-phys.net/7/3909/2007/.

Odum, J. R., Hoffmann, T., Bowman, F., Collins, D., Flagan, R. C., and Seinfeld, J. H.: Gas/particle partitioning and secondary organic aerosol yields, Environ. Sci. Technol., 30, 2580-2585, 1996.

Pandis, S. N., Harley, R. A., Cass, G. R., and Seinfeld, J. H.: Sec- 
ondary organic aerosol formation and transport, Atmos. Environ. A-Gen., 26, 2269-2282, 1992.

Pathak, R. K., Stanier, C. O., Donahue, N. M., and Pandis, S. N.: Ozonolysis of alpha-pinene at atmospherically relevant concentrations: Temperature dependence of aerosol mass fractions (yields), J. Geophys. Res.-Atmos., 112, D03201, doi:10.1029/2006jd007436, 2007.

Pierce, J. R., Engelhart, G. J., Hildebrandt, L., Weitkamp, E. A., Pathak, R. K., Donahue, N. M., Robinson, A. L., Adams, P. J., and Pandis, S. N.: Constraining particle evolution from wall losses, coagulation, and condensation-evaporation in smogchamber experiments: Optimal estimation based on size distribution measurements, Aerosol Sci. Tech., 42, 100-1015, doi:10.1080/02786820802389251, 2008.

Presto, A. A. and Donahue, N. M.: Investigation of a-pinene + ozone secondary organic aerosol formation at low total aerosol mass, Environ. Sci. Technol., 40, 3536-3543, 2006.

Sage, A. M., Weitkamp, E. A., Robinson, A. L., and Donahue, N. M.: Evolving mass spectra of the oxidized component of organic aerosol: results from aerosol mass spectrometer analyses of aged diesel emissions, Atmos. Chem. Phys., 8, 1139-1152, 2008, http://www.atmos-chem-phys.net/8/1139/2008/.

Song, C., Na, K., Warren, B., Malloy, Q., and Cocker, D. R.: Impact of propene on secondary organic aerosol formation from $\mathrm{m}$ xylene, Environ. Sci. Technol., 41, 6990-6995, 2007.

Stanier, C. O., Donahue, N., and Pandis, S. N.: Parameterization of secondary organic aerosol mass fractions from smog chamber data, Atmos. Environ., 42, 2276-2299, doi:10.1016/j.atmosenv.2007.12.042, 2008.

Stern, J. E.: Aerosol Formation and Growth in Aromatic Hydrocarbon/ $\mathrm{NO}_{\mathrm{x}}$ Systems, Doctor of Philosophy, Chemical Engineering, California Institute of Technology, Pasadena, USA, 632 pp., 1988.

Takekawa, H., Minoura, H., and Yamazaki, S.: Temperature dependence of secondary organic aerosol formation by photo-oxidation of hydrocarbons, Atmos. Environ., 37, 3413-3424, 2003.
Volkamer, R., Jimenez, J. L., San Martini, F., Dzepina, K., Zhang, Q., Salcedo, D., Molina, L. T., Worsnop, D. R., and Molina, M. J.: Secondary organic aerosol formation from anthropogenic air pollution: Rapid and higher than expected, Geophys. Res. Lett., 33, L17811, doi:10.1029/2006g1026899, 2006.

Volkamer, R., Ziemann, P. J., and Molina, M. J.: Secondary Organic Aerosol Formation from Acetylene $\left(\mathrm{C}_{2} \mathrm{H}_{2}\right)$ : seed effect on SOA yields due to organic photochemistry in the aerosol aqueous phase, Atmos. Chem. Phys., 9, 1907-1928, 2009, http://www.atmos-chem-phys.net/9/1907/2009/.

Vutukuru, S., Griffin, R. J., and Dabdub, D.: Simulation and analysis of secondary organic aerosol dynamics in the South Coast Air Basin of California, J. Geophys. Res.-Atmos., 111, D10S12, doi:10.1029/2005jd006139, 2006.

Weitkamp, E. A., Sage, A. M., Pierce, J. R., Donahue, N. M., and Robinson, A. L.: Organic aerosol formation from photochemical oxidation of diesel exhaust in a smog chamber, Environ. Sci. Technol., 41, 6969-6975, doi:10.1021/es070193r, 2007.

Zhang, J. Y., Hartz, K. E. H., Pandis, S. N., and Donahue, N. M.: Secondary organic aerosol formation from limonene ozonolysis: Homogeneous and heterogeneous influences as a function of $\mathrm{NO}_{\mathrm{x}}$, J. Phys. Chem. A, 110, 11053-11063, 2006.

Zhang, Q., Jimenez, J. L., Canagaratna, M. R., Allan, J. D., Coe, H., Ulbrich, I., Alfarra, M. R., Takami, A., Middlebrook, A. M., Sun, Y. L., Dzepina, K., Dunlea, E., Docherty, K., DeCarlo, P. F., Salcedo, D., Onasch, T., Jayne, J. T., Miyoshi, T., Shimono, A., Hatakeyama, S., Takegawa, N., Kondo, Y., Schneider, J., Drewnick, F., Borrmann, S., Weimer, S., Demerjian, K., Williams, P., Bower, K., Bahreini, R., Cottrell, L., Griffin, R. J., Rautiainen, J., Sun, J. Y., Zhang, Y. M., and Worsnop, D. R.: Ubiquity and dominance of oxygenated species in organic aerosols in anthropogenically-influenced Northern Hemisphere midlatitudes, Geophys. Res. Lett., 34, L13801, doi:10.1029/2007g1029979, 2007. 